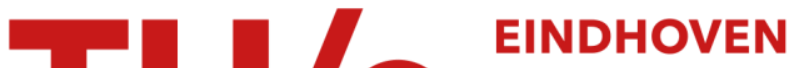 \\ UNIVERSITY OF \\ TECHNOLOGY
}

\section{Surface characterization in catalysis: An area of conflicting requirements}

Citation for published version (APA):

Niemantsverdriet, J. W. (1989). Surface characterization in catalysis: An area of conflicting requirements. Ultramicroscopy, 27(2), 212-212. https://doi.org/10.1016/0304-3991(89)90136-8

DOI:

10.1016/0304-3991(89)90136-8

Document status and date:

Published: 01/01/1989

\section{Document Version:}

Publisher's PDF, also known as Version of Record (includes final page, issue and volume numbers)

\section{Please check the document version of this publication:}

- A submitted manuscript is the version of the article upon submission and before peer-review. There can be important differences between the submitted version and the official published version of record. People interested in the research are advised to contact the author for the final version of the publication, or visit the $\mathrm{DOI}$ to the publisher's website.

- The final author version and the galley proof are versions of the publication after peer review.

- The final published version features the final layout of the paper including the volume, issue and page numbers.

Link to publication

\section{General rights}

Copyright and moral rights for the publications made accessible in the public portal are retained by the authors and/or other copyright owners and it is a condition of accessing publications that users recognise and abide by the legal requirements associated with these rights.

- Users may download and print one copy of any publication from the public portal for the purpose of private study or research.

- You may not further distribute the material or use it for any profit-making activity or commercial gain

- You may freely distribute the URL identifying the publication in the public portal.

If the publication is distributed under the terms of Article 25fa of the Dutch Copyright Act, indicated by the "Taverne" license above, please follow below link for the End User Agreement:

www.tue.nl/taverne

Take down policy

If you believe that this document breaches copyright please contact us at:

openaccess@tue.nl

providing details and we will investigate your claim. 
inclusions are sometimes present which seem to have a different cooling history from the host chondrule itself. The sizes of these inclusions vary from 1 to $30 \mathrm{\mu m}$. Three different micro-analytical instruments were used to investigate these glass inclusions in the Allende meteorite.

1) An electron microprobe to determine the low $\mathrm{Z}$ elements, present in a relatively high concentration.

2) A proton microprobe, to determine low concentrations of elements with $\mathrm{Z}>19$, using micro-PIXE.

3) A micro-Raman spectrometer, to investigate the presence and the ordering of carbon in the inclusions, because this element is particularly sensitive to the temperature of solidification.

From the measurements it was concluded that the glass inclusions did form after the crystalization of the chondrules out of a residual melt and not by recrystallization of part of the chondrules as shown by the different chemical composition. The abundance of carbon is not very well understood up to now, and we will invstiqate more meteorites to improve the data base available, in order to collect more evidence for the present cooling model.

\section{SURFACE CHARACTERIZATION IN CATALYSIS: AN AREA OF CONFLICTING REQUIREMENTS}

\section{J.W. Niemantsverdriet}

\author{
Laboratory of Inorganic Chemistry and \\ Catalysis, Eindhoven University of \\ Technology, 5600 MB Eindhoven, \\ The Netherlands
}

During the last decade, experiments with single crystal surfaces in surface science have contributed to the view that the catalytic properties of a surface are determined by its local composition and structure. The ultimate goal of catalyst characterization should therefore be to study the surface composition and structure of a catalyst on the atomic scale. Because the state of a surface depends critically on the nature of the ambient atmosphere, a further requirement is that the characterization should be carried out under reaction conditions rather than in ultra high vacuum. The performance of a number of frequently used spectroscopies in catalysis are reviewed in the light of the requirements outlined above.
EXCHANGE OF ATOMS ACROSS ATOMICALLY SHARP INTERFACES

J.W. Niemantsverdriet, K. Markert*, P. Dolle* and $K$. Wandelt*

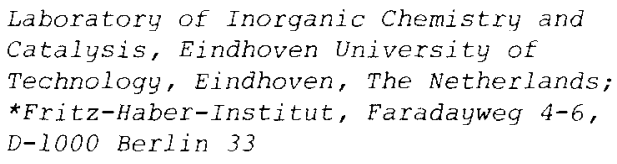

The thermal stability of interfaces is of great importance for the design and application of multilayered structures. Here we report on the thermally activated site exchange between atoms across atomically sharp Ag/Au interfaces by using photoemission of adsorbed xenon (PAX). The model interface was formed by first preparing a monolayer of $\mathrm{Au}$ on a Ru(001) substrate, and then depositing at $60 \mathrm{~K}$ a submonolayer quantity of Ag on top. Neither Au nor Ag penetrate the Ru substrate. PAX shows that upon annealing at $275 \mathrm{~K}$, monoatomically thick $\mathrm{Ag}$ islands form on the Au. This structure constitutes the model interface. Exchange between $\mathrm{Ag}$ in the second and $\mathrm{Au}$ in the first layer on Ru starts at temperatures around $350 \mathrm{~K}$, but occurs exclusively within the area of the Ag islands. The formation of a uniform AgAu alloy throughout both layers requires annealing temperatures as high as $760 \mathrm{~K}$. The results can qualitatively be understood in terms of the lateral $\mathrm{Ag}-\mathrm{Ag}$ and Au-Au interactions, the vertical Au-Ru and $\mathrm{Ag}-\mathrm{Ru}$ interactions, the activation energies for surface and bulk diffusion and the heats of alloy formation between $\mathrm{Ag}$ and $\mathrm{Au}$.

\section{EDGE EFFECTS IN SEM AND SAM}

\section{B.F. Ottexloo and J.L.G. Suijker}

Philips Research Laboratories, P.O. Box 80.000, 5600 JA Eindhoven, The Netherlands

Two analytical techniques, the Scanning Electron Microscopy and the Scanning Auger Microscopy, depend on the same physical processes for their image formation. Both techniques are used to analyze problems in IC manufacturing. The SEM is used routinely to measure linewidths, contact hole sizes, etc. The SAM gives the chemical composition of these structures and their residues after 